\title{
The presence of microplastics in the digestive tract of commercial fishes off Pantai Indah Kapuk coast, Jakarta, Indonesia
}

\author{
AYU RAMADHINI HASTUTI ${ }^{1, \boldsymbol{v}}$, DJAMAR T.F. LUMBANBATU ${ }^{2}$, YUSLI WARDIATNO ${ }^{2,3,4, \boldsymbol{}, ~}$ \\ ${ }^{1}$ Program in Aquatic Resources Management, Graduate School, Institut Pertanian Bogor. Jl. Raya Dramaga, Kampus IPB Darmaga, Bogor 16680, West \\ Java, Indonesia. "email: ramadhiniayu@ gmail.com. \\ ${ }^{2}$ Department of Aquatic Resources Management, Faculty of Fisheries and Marine Sciences, Institut Pertanian Bogor. Jl. Raya Dramaga, Kampus IPB \\ Darmaga, Bogor 16680, West Java, Indonesia. \\ ${ }^{3}$ Environmental Research Center (PPLH-IPB), Institut Pertanian Bogor. Jl. Raya Dramaga, Kampus IPB Darmaga, Bogor 16680, West Java, \\ Indonesia."vemail: yusli@ipb.ac.id. \\ ${ }^{4}$ Center for Coastal and Marine Resources Studies (PKSPL-IPB), Institut Pertanian Bogor. Jl. Raya Pajajaran, Kampus IPB Baranangsiang, Bogor 16143, \\ West Java, Indonesia.
}

Manuscript received: 9 April 2019. Revision accepted: 17 April 2019

\begin{abstract}
Hastuti AR, Lumbanbatu DTF, Wardiatno Y. 2019. The presence of microplastics in the digestive tract of commercial fishes off Pantai Indah Kapuk coast, Jakarta, Indonesia. Biodiversitas 20: 1233-1242. Microplastics in fishes have been reported in many studies due to their threat to marine fishes and human health. But only a few data exist on commercial fish for human consumption in Indonesia. This study revealed the presence of microplastics in the digestive tract of 9 commercial species collected from six sites along the Pantai Indah Kapuk coast. Ingested microplastics were identified using gut content analysis. Microplastic particles were counted and categorized by type, color, and size. 169 of 174 (97.13\%) of examined fish had microplastics. A total of 2063 microplastic particles were collected with the average number of particles per individual of $12.21 \pm 9.76$. The highest number $\left(20.0 \pm 8.0\right.$ particles individual $^{-}$ $\left.{ }^{1}\right)$ was found in Sardinella fimbriata and the lowest one $\left(4.9 \pm 4.7\right.$ particles individual $\left.^{-1}\right)$ was found in Oreochromis mossambicus. Majority of ingested particles were fibers $(89.63 \%)$, followed by fragments $(6.24 \%)$, films $(4.13 \%)$ and no pellets were observed. In terms of color, the most abundant were transparent particles $(79.20 \%)$, followed by blue $(7.03 \%)$, red $(3.54 \%)$, black $(2.86 \%)$, green $(2.71 \%)$, and others which were found in low number. The highest number of fibers by size was <20-100 $\mu \mathrm{m}(55.03 \%)$, films were $100-$ $1000 \mu \mathrm{m}(33.93 \%)$, and fragments were $<100 \mu \mathrm{m}(25.25 \%)$. Microplastics ingested per individual in each species were not correlated to total body length, total body weight, digestive tract length, digestive content weight, mouth height, and mouth length.
\end{abstract}

Keywords: estuary, gut content, Jakarta Bay, marine debris, pollution

\section{INTRODUCTION}

According to NOAA (2013), marine debris is "any persistent solid material that is manufactured or processed and directly or indirectly, intentionally or unintentionally, disposed of or abandoned into the marine environment". Plastics are dominant type of marine debris in estuaries (Costa et al. 2011; Smith 2012; Ivar do sul and Costa 2013; Hastuti 2014). Plastic in the marine environment can be fragmented into smaller particles with similar composition which is influenced by UV-radiation, abrasion, seawater hydrolysis, and oxidation (Moore 2008). The larger plastics can be fragmented into micro and nano-sized (Pinto da Costa et al. 2016). Some studies defined microplastics in size $<5 \mathrm{~mm}$, while the other defined microplastics in size $<1 \mathrm{~mm}$ (Hidalgo-Ruz et al. 2012). It means that microplastics can be divided into 2 size fractions, small $(<1$ $\mathrm{mm})$ and large $(1-5 \mathrm{~mm})$ particles. Plastics fragmented are the secondary plastics while primary plastics are intentionally made be that size (Stevenson 2011). A reduction in the size of plastic particles potentially increases chemical effects while large plastics may increase physical effects (UNEP 2011). Some previous studies showed that microplastics spread on sea surface (Lattin et al. 2004), marine sediment (Claessens et al. 2011), mangrove sediment (Nor and Obbard 2014; Hastuti 2014), and along shoreline (Van Cauwenberghe et al. 2013).

Some of microplastic polymers have lower density than seawater density (Enders et al. 2015). It may leach into river from terrestrial and be transported to marine environment (Cheung et al. 2018). According to Browne et al. (2013), microplastics can pass through or be accumulated in the digestive tract of marine organism. Microplastics are also potentially available to planktivorous organisms because of their small size (Wright et al. 2013). Microplastics can be translocated from lower trophic level organisms to higher trophic level organisms through the food web (Teuten et al. 2009; Anastasopoulou et al. 2013; Pegado et al. 2018).

Microplastics were found in various biota, such as bivalve (Su et al. 2018; Van Cauwenberghe and Janssen 2014; Qu et al. 2018), crustacea (Carreras-Colom et al. 2018), cetacean (Lusher et al. 2015), seagrass (Goss et al. 2018), seabird (Alvarez et al. 2018), and plankton (Frias et al. 2014). There are 3 impacts of ingested microplastics: (i) to be accumulated and block the digestive tract and disrupt digestion process, (ii) to become dissolution of chemical components after digestion, and (iii) to have accumulation 
of chemical components into the organs (Teuten et al. 2007). The potential of microplastic ingestion depends on the abundance of microplastics in environment and their widespread in the ocean (Thompson et al. 2004), particles type and shape (Canniff and Hoang 2018), size (Moore 2008; Christina Fossi et al. 2012; Canniff and Hoang 2018) and color similar to their prey (Setala et al. 2014).

The occurrence of microplastics in the digestive tract of fishes has been reported in many studies, but little knowledge of their existence in commercial fishes for human consumption in Indonesia. A previous study showed that microplastics were found in mangrove sediment of Pantai Indah Kapuk coast, Jakarta, Indonesia (Hastuti 2014), but there is no data on the digestive tract of commercial fishes. The aim of this study was to reveal the potential threats of ingested microplastics by commercial fishes along Pantai Indah Kapuk coast. This study identified and quantified the occurrence of microplastics ingestion as baseline data for future comparison.

\section{MATERIALS AND METHODS}

\section{Study area}

The research was conducted in Pantai Indah Kapuk coast; an estuary located in the north of Jakarta, Indonesia. Sampling location represented three estuary regions: St 1 and St 2 represented Angke Kapuk Nature Tourism Park, St 3 and St 4 represented Protected Forest area, and St 5 and St 6 represented Muara Angke Sanctuary (Figure 1). These areas are surrounded by mangrove ecosystem as habitat for many aquatic organisms, including commercial valuable fishes. The estuary also has an important economic value for industry, fishing harbors, and recreational areas. There are 3 rivers ended in the coast, i.e., Kamal River, Cengkareng Drain River, and Angke River. Consequently, the estuary has also under anthropogenic and industrial pressures from terrestrial and coastal area. The water pollution level and marine debris pollution were very high including the microplastic pollution in mangrove sediment (Hastuti 2014).

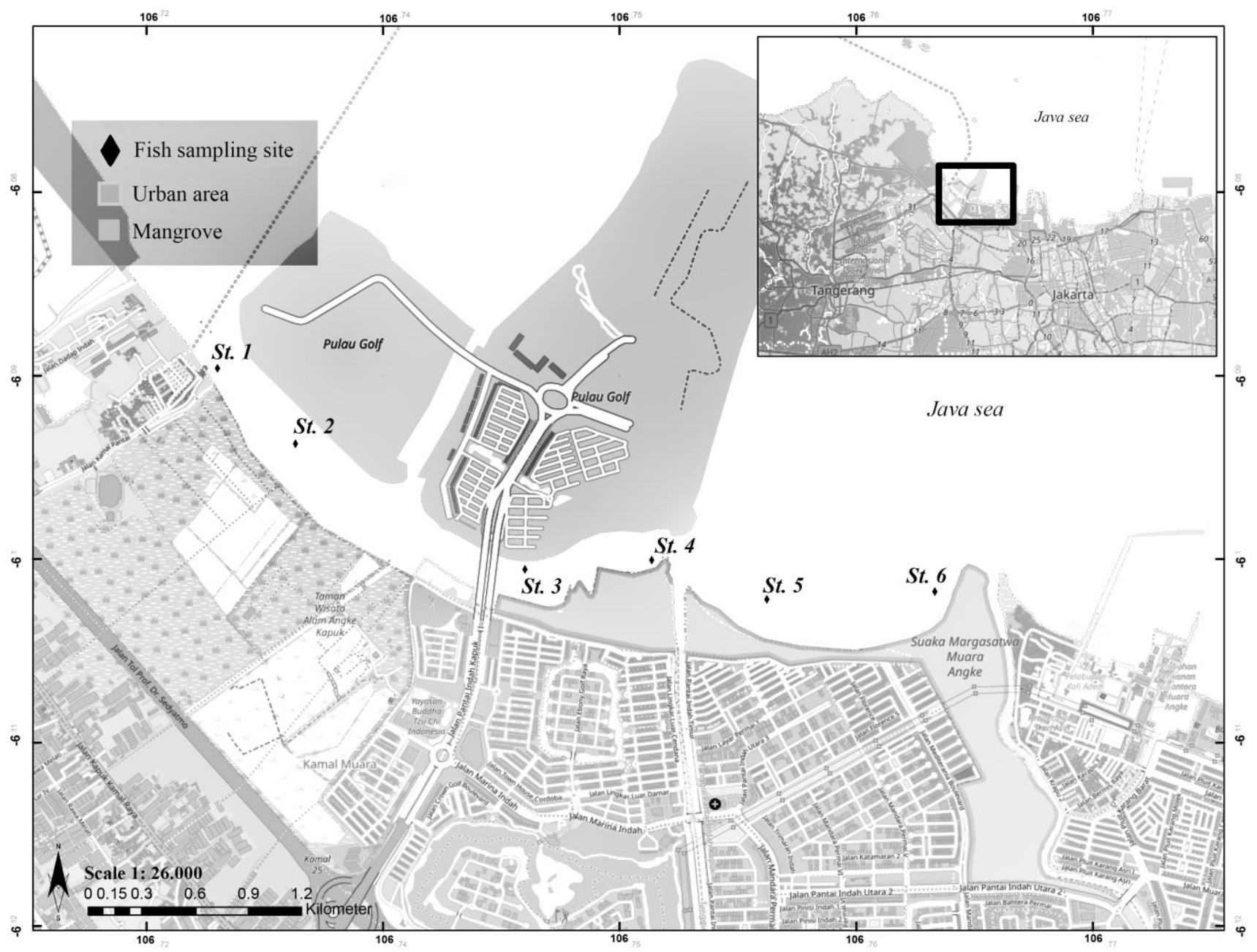

Figure 1. Map of the Pantai Indah Kapuk coast showing the sampling location, North Jakarta, Indonesia. Small black diamonds represent fish sampling sites 


\section{Procedures}

Fish sampling

Fish were collected in six stations along Pantai Indah Kapuk coast from March to July 2015. Six gillnets (30x1.5 m) with $2 \times 2 \mathrm{~cm}$ mesh size were operated in each station. All of collected individuals were labeled and stored in cooling box $\left(4^{\circ} \mathrm{C}\right)$ during transportation. These fishes were measured immediately in total length using ruler (accuracy $1 \mathrm{~mm}$ ), weight using digital balance (accuracy $1 \mathrm{~g}$ ), mouth height and mouth width using caliper (accuracy $0.01 \mathrm{~mm}$ ). These fishes were then dissected to remove the digestive tract (gut and stomach), then it was preserved in $4 \%$ formaldehyde for further analysis.

\section{Sample processing}

Digestive tract (gut and stomach) was measured in length using ruler (accuracy $1 \mathrm{~mm}$ ) and weight using digital balance (accuracy $0.0001 \mathrm{~g}$ ). Digestive tract was dissected to take out the stomach and gut content. The stomach and gut content were weighed and the volume was measured. The digestive tract content was diluted in $\mathrm{NaCl}$ saturated solution to extract the microplastic particles. Digestive tract content was examined into natural prey and microplastics under a microscope (10x10 magnifications). Microplastic particles were identified by abundance (particles individual-1) and categorized by type (film, fiber, fragment, dan pellet), color (transparent, blue, red, black, green, orange, yellow, and purple), and size $(<20-5000$ $\mu \mathrm{m}$ for fiber, $<200->100.000 \mu \mathrm{m}$ for film, and $<100-$ $>5000 \mu \mathrm{m}$ for fragment) using micrometer.

\section{Data analysis}

Descriptive statistical analysis was used to display the data in table, diagram, and graph. Data was showed on average \pm standard deviation and range. All statistical analyses were performed using SPSS software. Normality test was applied by Kolmogorov-Smirnov test to evaluate the type of data (parametric or nonparametric) before further analysis. The nonparametric Kruskal-Wallis test was used for multiple comparisons. If the test showed a significantly different result, the non-parametric MannWhitney test was used for pairwise comparison. KruskalWallis test was applied to compare the number of microplastic particles per individual among groups (carnivore and herbivore) and species. While MannWhitney test was applied to compare the number of microplastic ingested within species. Spearman Rank Correlation test was used for nonparametric correlation to evaluate the correlation between the number of microplastic particles and fish morphometric (total body weight, total body length, digestive tract length, digestive content weight, mouth height, and mouth width) with significance level 0.01 .

\section{RESULTS AND DISCUSSION}

\section{The abundances of microplastic ingested}

A total of 174 individuals, representing the Actinopterygii group (ray-finned fishes) could be collected from six sampling sites. Overall, all collected fishes were grouped into 5 order, 7 family, and 9 species (Table 1). The majority of the fishes being examined were part of the Perciformes order. According to digestive tract analysis, all digestive content of fishes being examined were completely full. Nine species of fishes being examined showed diverse diets. Five species ingested mostly phytoplankton while the other 4 species ingested almost all zooplankton. Based on that, these fishes were grouped into two groups based on their natural prey, herbivorous and carnivorous fish. Precisely, 169 of 174 (97.13\%) the fish were examined had microplastics. A total of 2063 microplastic particles were found in 169 individuals.

The lowest number of fishes containing microplastics were found in Oreochromis mossambicus (70\%), followed by Chanos chanos (90\%), and Scatophagus argus (97\%). While on the other species, all specimens had microplastics in the digestive tract. The lowest range of microplastic particles per individual was found in Oreochromis mossambicus (0-13 particles individual $\left.{ }^{-1}\right)$ and the highest was found in Siganus canaliculatus (4-52 particles individual $^{-1}$ ) (see Table 1). The average number of particles per individual was $12.21 \pm 9.76$ particle individual $^{-1}$, with the highest average number of particles $(20 \pm 8$ particles individual $^{-1}$ ) was collected from Sardinella fimbriata and the lowest average number of particles $(4.9 \pm 4.7$ particles individual $^{-1}$ ) was collected from Oreochromis mossambicus (Figure 2).

Average number of microplastic particles per individual was low in Oreochromis mossambicus $(4.90 \pm 4.7$ particles individual $\left.^{-1}\right)$, followed by Scatophagus argus $(5.89 \pm 4.2$ particles individual $\left.{ }^{-1}\right)$, Crenimugil seheli $(9.17 \pm 11.9$ particles individual $\left.^{-1}\right)$, Chanos chanos $(9.70 \pm 7.3$ particles individual $\left.^{-1}\right)$, and Mugil cephalus $(10.07 \pm 6.4$ particles individual $\left.^{-1}\right)$. These fishes are omnivore, tend to be herbivore. These fishes had a longer digestive tract than other species. While average number of microplastic particles per individual were high in Sardinella fimbriata $\left(20.00 \pm 8.0\right.$ particles individual $\left.^{-1}\right)$, followed by Siganus canaliculatus $\left(18.06 \pm 10.8\right.$ particles inividual $\left.^{-1}\right)$, Abalistes stellaris $\left(16.33 \pm 11.1\right.$ particles individual $\left.{ }^{-1}\right)$, and Anodontostoma chacunda (14.00 \pm 7.9 particles individual $^{-}$ $\left.{ }^{1}\right)$. These fishes are omnivore; tend to be carnivore that had a shorter digestive tract than other fish species.

Mann-Whitney test showed that the number of microplastics is significantly different between herbivore and carnivore $(\mathrm{p}<0.01)$. Kruskal-Wallis test indicated that there are at least one species containing microplastics that are significantly different. Further analysis using MannWhitney test showed that the number of ingested microplastics per individual is significantly different between each species from herbivorous fishes and carnivorous fishes. 
Table 1. The presence of microplastic particles in the digestive tract of fishes collected from Pantai Indah Kapuk coast, Jakarta, Indonesia

\begin{tabular}{|c|c|c|c|c|c|}
\hline Order & Family & Species & $\begin{array}{l}\text { Number } \\
\text { of fish } \\
\text { examined }\end{array}$ & $\begin{array}{l}\text { Number of } \\
\text { fish } \\
\text { containing } \\
\text { microplastics }\end{array}$ & $\begin{array}{l}\text { Range of } \\
\text { microplastic } \\
\text { particles per } \\
\text { individual }\end{array}$ \\
\hline \multirow[t]{3}{*}{ Perciformes } & Cichlidae & Oreochromis mossambicus (Peters, 1852) & 10 & 7 & $0-13$ \\
\hline & Scatophagidae & Scatophagus argus (Linnaeus, 1766) & 35 & 34 & $0-16$ \\
\hline & Siganidae & Siganus canaliculatus (Park, 1797) & 30 & 30 & $4-52$ \\
\hline Mugiliformes & Mugilidae & Crenimugil seheli (Forsskal, 1775) & 12 & 12 & $1-39$ \\
\hline Gonorynchiformes & Chanidae & Chanos chanos (Forsskal, 1775) & 10 & 9 & $0-23$ \\
\hline \multirow[t]{2}{*}{ Clupeiformes } & Clupeidae & Anodontostoma chacunda (Hamilton, 1822) & 10 & 10 & $7-33$ \\
\hline & & Sardinella fimbriata (Valenciennes, 1847) & 10 & 10 & $7-33$ \\
\hline Tetraodontiformes & Balistidae & Abalistes stellaris (Bloch \& Schneider, 1801) & 30 & 30 & $2-50$ \\
\hline
\end{tabular}

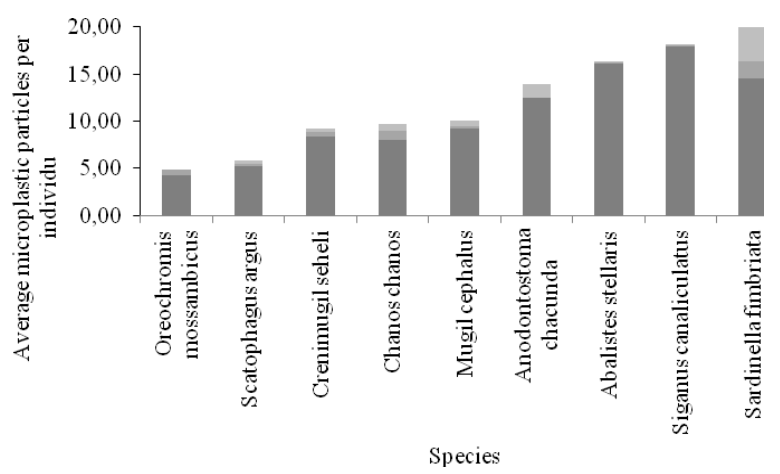

Figure 3. Average number of fibers $(\square)$, films $(\square)$, and fragments (口) per species

\section{Type of ingested microplastics}

The majority $(89.63 \%)$ of plastic particles were fibers. Fibers were found in all species. Films $(4.13 \%)$ were found in most species, while some individuals of Anodontostoma chacunda had no films. Fragments $(6.24 \%)$ were found in most species, while some individuals of Oreochromis mossambicus had no fragments. However, no pellets were observed (Figure 3).

The highest number of fibers were found respectively in Siganus canaliculatus $\left(17.97 \pm 5.8\right.$ particles individu $\left.{ }^{\text {al-1 }}\right)$, Abalistes stellaris $\left(16.07 \pm 11.05\right.$ particles individu $\left.^{\text {al-1 }}\right)$, Sardinella fimbriata $\left(14.60 \pm 6.09\right.$ particles individu $\left.{ }^{\mathrm{al}-1}\right)$, Anodontostoma chacunda $\left(12.50 \pm 6.7\right.$ particles individu ${ }^{\mathrm{a}-}$ $\left.{ }^{1}\right)$, Mugil cephalus $\left(9.26 \pm 6.1\right.$ particles individu $\left.{ }^{\mathrm{al}-1}\right)$, Crenimugil seheli $\left(8.42 \pm 11.9\right.$ particles individu $\left.{ }^{\mathrm{al}-1}\right)$, Chanos chanos $\left(8.00 \pm 6.3\right.$ particles individu $\left.{ }^{\mathrm{al}-1}\right)$, Scatophagus argus $\left(5.22 \pm 4.3\right.$ particles individu $\left.{ }^{\mathrm{al}-1}\right)$, and Oreochromis mossambicus $\left(4.30 \pm 4.7\right.$ particles individu ${ }^{\mathrm{a}-}$ $1)$.

The highest number of films were found respectively in Sardinella fimbriata $\left(1.80 \pm 2.8\right.$ particles individu $\left.{ }^{-1}\right)$, Chanos chanos $\left(1.00 \pm 1.4\right.$ particles individu $\left.^{-1}\right)$, Oreochromis mossambicus $\left(0.60 \pm 0.7\right.$ particles individu $\left.{ }^{-1}\right)$, Crenimugil seheli $\left(0.42 \pm 1.1\right.$ particles individu $\left.{ }^{-1}\right)$, Scatophagus argus $\left(0.28 \pm 0.6\right.$ particles individu $\left.{ }^{-1}\right)$, Mugil cephalus $\left(0.19 \pm 0.6\right.$ particles individu $\left.{ }^{-1}\right)$, Abalistes stellaris

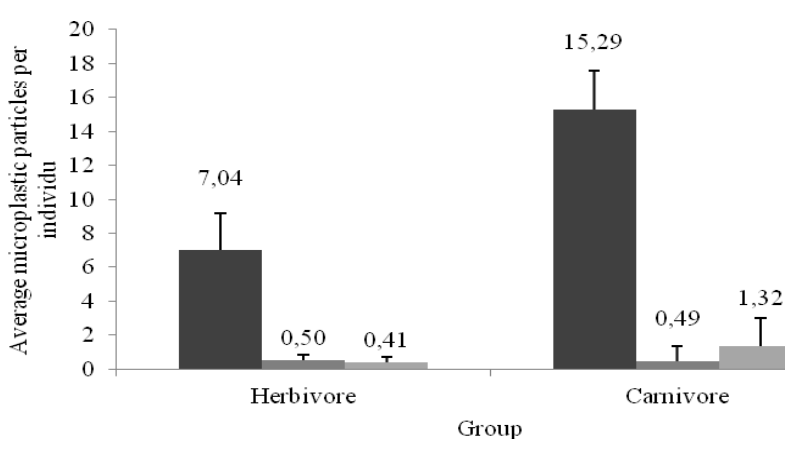

Figure 4. Average number of fibers ( $\square$ ), films ( $\square$ ), and fragments (Ш) per group

$\left(0.13 \pm 0.6\right.$ particles individu $\left.{ }^{-1}\right)$, and Siganus canaliculatus $\left(0.03 \pm 0.01\right.$ particles individu $\left.{ }^{-1}\right)$.

The highest number of fragments were found respectively in Sardinella fimbriata $(3.60 \pm 3.7$ particles individu $\left.^{-1}\right)$, Anodontostoma chacunda $(1.50 \pm 1.4$ particles individu $\left.^{-1}\right)$, Chanos chanos $\left(0.70 \pm 1.1\right.$ particles individu $\left.^{-1}\right)$, Mugil cephalus $\left(0.63 \pm 2.3\right.$ particles individu $\left.^{-1}\right)$, Scatophagus argus $\left(0.39 \pm 0.5\right.$ particles individu $\left.^{-1}\right)$, Crenimugil seheli $\left(0.33 \pm 0.6\right.$ particles individu $\left.{ }^{-1}\right)$, Abalistes stellaris $\left(0.13 \pm 0.4\right.$ particles individu $\left.{ }^{-1}\right)$, and Siganus canaliculatus $\left(0.06 \pm 0.02\right.$ particles individu $\left.^{-1}\right)$.

Microplastics within the two groups (herbivore and carnivore) consisted predominantly of fibers. Fibers $(15.29 \pm 2.3$ particles individu $\left.^{\text {al- }-1}\right)$ and fragments $\left(1.32 \pm 1.6\right.$ particles individu $\left.^{\text {al- }-1}\right)$ were higher in carnivorous fishes than herbivorous fishes, whereas, films were found in similar number between herbivore $(0.50 \pm 0.3$ particles individu $\left.{ }^{\mathrm{a}-1}\right)$ and carnivore $(0.49 \pm 0.8$ particles individu $^{\text {al-1 }}$ ) (Figure 4).

\section{Colors of ingested microplastics}

Plastic particles were categorized into 8 colors. The most abundant (79.2\%) (1634 of 2063 particles) were transparent, followed by blue (145 of 2063 particles), red (73 of 2063 particles), black (59 of 2063 particles), and green (56 of 2063 particles). Other colors were found in low number, ranged from $0.48 \%$ to $2.57 \%$ (Figure 5). 


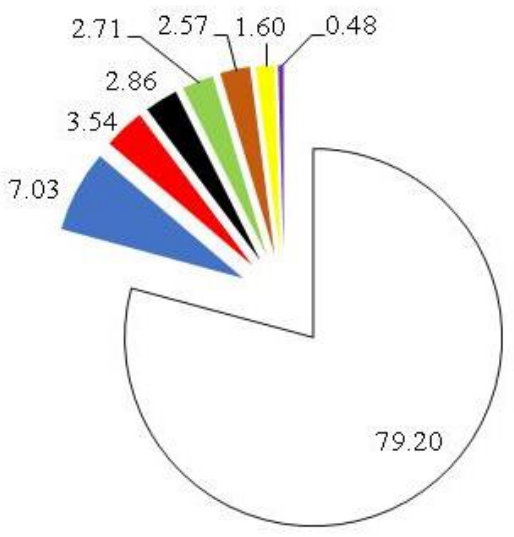

Figure 5. Percent of microplastic particles by color transparent $(\square)$, blue ( $\square)$, red ( $\square$ ), black $(\square)$, green $(\square)$, orange $(\square)$, yellow ( ), purple $(\square)$ in the digestive tract of fishes collected from Pantai Indah Kapuk coast, Jakarta, Indonesia

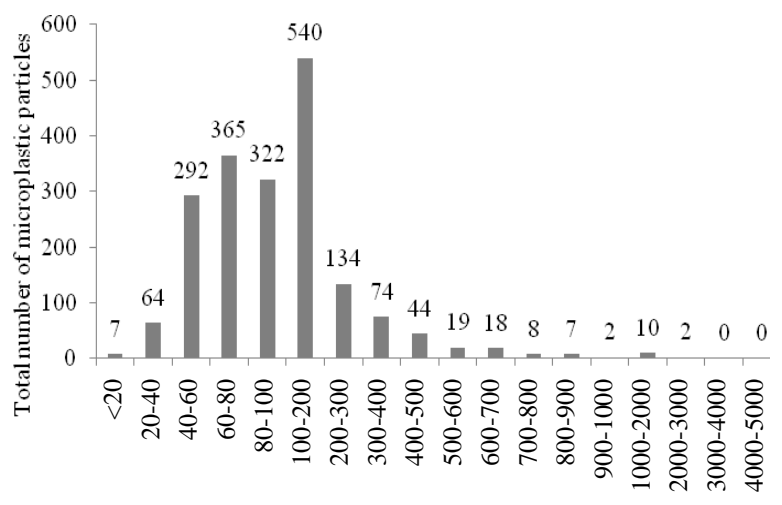

Size (um)

Figure 6. Total number of fibers by size collected from digestive tracts of commercial fishes off Pantai Indah Kapuk coast, Jakarta, Indonesia

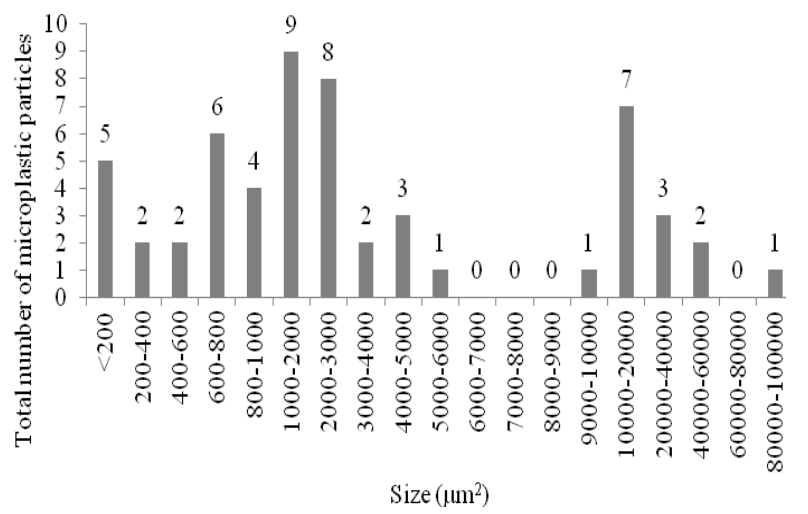

Figure 7. Total number of films by size collected from digestive tracts of commercial fishes off Pantai Indah Kapuk coast, Jakarta, Indonesia

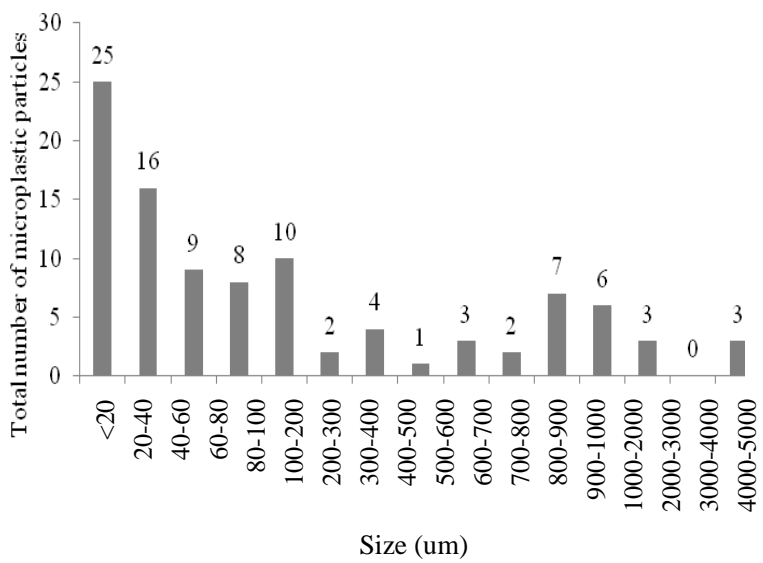

Figure 8. Total number of fragments by size collected from digestive tracts of commercial fishes off Pantai Indah Kapuk coast, Jakarta, Indonesia

\section{Size of ingested microplastics}

Microplastic particles were classified based on length (for fiber) and width (for film and fragment). The size of fibers ranged $<20$ to $3000 \mu \mathrm{m}$. The highest numbers $(1050$ of 1908 particles) were $<20-100 \mu \mathrm{m}$ with the dominant size (365 particles) were $60-80 \mu \mathrm{m}$. The size range $100-200 \mu \mathrm{m}$ were found as much as $28.30 \%$ ( 540 of 1908 particles). The number of particles decreases with increasing size of particles (Figure 6). Unfortunately, 6 macrofiber particles $(>5000 \mu \mathrm{m}$ ) were also found in Scatophagus argus.

The number of film particles varied between <200$100.000 \mu \mathrm{m}^{2}$. The most abundant (19 of 56 particles) were particles between $100-1000 \mu \mathrm{m}^{2}$ with the dominant size were found between 600 to $800 \mu \mathrm{m}^{2}$, followed by 1000 $2000 \mu \mathrm{m}^{2}$ particles.

Overall, the size of fragments collected was lower than the size of films. Fragments were found in various size between $<100$ to $5000 \mu \mathrm{m}^{2}$ (99 particles in total). The dominant size $(25.25 \%)$ were $<100 \mu \mathrm{m}^{2}$ particles. While $>1000 \mu \mathrm{m}^{2}$ particles were only found in Anodontostoma chacunda, Abalistes stellaris, Siganus canaliculatus, dan Sardinella fimbriata that were carnivorous fishes.

\section{The correlation between ingested microplastics and fish morphometry}

In the same species, there was no correlation within individual between the number of ingested microplastics and total body weight, total body length, digestive tract length, digestive content weight, mouth height, and mouth length. Then, we tried to correlate ingested microplastics and fish morphometry of all collected individual.

Overall, Spearman Rank Correlation test confirmed that the number of microplastics per individual were negative correlated to total body weight $(r=-0.426, p<$ $0.01)$ and total length $(\mathrm{r}=-0.370, p<0.01)$. This finding suggested that carnivorous fishes contain higher number of microplastics than herbivorous fishes, even though they had smaller body size. 
Spearman Rank Correlation test also confirmed that there was a significant negative correlation between the number of particles per species and digestive tract length ( $\mathrm{r}$ $=-0.492, p<0.01)$ and digestive content weight $(\mathrm{r}=$ $0.253, p<0.01$ ). The size of digestive tract was related to feeding behavior. With shorter digestive tract length, carnivorous fishes had higher number of microplastics than herbivorous fishes.

Spearman Rank Correlation test also confirmed that the number of microplastics per individual were negative correlated to mouth height $(\mathrm{r}=-0.341, p<0.01)$ and mouth width $(\mathrm{r}=-0.340, p<0.01)$. This finding suggested that carnivorous fishes ingested higher number of microplastics than herbivorous fishes, even though they had smaller mouth opening due to their small body size.

\section{Discussion}

Collected fishes and their threats to human health

Microplastic pollution in the environment of Jakarta Bay was demonstrated by Manalu et al. (2017). This study provides the first evidence of microplastics in digestive tract of commercial fishes in Pantai Indah Kapuk coast. These fishes were caught close to the mouth of 3 rivers (Kamal River, Cengkareng Drain River, and Angke River) that contribute the microplastics particles into the coast and marine environment. All of collected fish have an ecological range between freshwater to brackish water. This results support the notion that salinity ranged between 1-15 psu in Pantai Indah Kapuk coast (Hastuti 2014). The most collected fish were Perciformes orders that consist of 3 families (Cichlidae, Scatophagidae, and Siganidae). Perciformes were dominant in almost all oceans (Simanjuntak et al. 2011). All of collected species were the commercial fishes which were daily caught and consumed by people along the estuary. It might be threat to human health due to their consumption.

Primary plastics were made of hydrophobic materials. Chemical contaminants from environment may be accumulated in the surface, so this environment can be reservoirs of toxic chemicals (Ivar do Sul and Costa 2014). The examined commercial fishes containing microplastics could be a route for transportation of toxic chemical into human via their consumption. Plastics were made of chemical materials including polychlorinated biphenyl (PCBs), polycyclic aromatic hydrocarbon (PAH), petroleum hydrocarbon, organochlorine pesticides, polybrominated diphenyl ethers, alkylphenol, and bisphenol that may cause chronic effects to human health by deterioration of human immune and endocrine disruption (Teuten et al. 2009). So, microplastics ingestion by commercial fishes becomes the global concern due to their threat to human health.

\section{The occurrence of microplastics ingestion}

The occurrence of microplastic ingestion in fishes has been reported by some previous studies. The number of ingested microplastics in this study was relatively high compared to similar studies (Table 2). The high percentage of ingestion (58\%) was reported by Guven et al. (2017) in Mediterranean Sea, while this study reported the highest percentage of ingestion was $97.13 \%$ of 176 individual. The highest number of ingested microplastic was also reported in recent study, i.e., 2063 particles which were extracted from 169 individual of fishes. Those previous studies found an average of 1-2 particles of ingested plastic per individual, which was a lower value than the average ingested microplastics in this recent study, i.e. 12.21 particles individu ${ }^{\mathrm{a}-1}$. However, the comparison of our results with other studies was difficult due to the differences in species, method, and sampling location. Fishes in this study were caught near the mouth of 3 rivers. The highest microplastics ingestion was shown at the mouth of the river (Neves et al. 2015).

All collected species in this study were planktonic fishes that swallow their prey as they do filtering an amount of water (filter feeding). Microplastic particles are bioavailable for planktonic organisms because they are found within plankton in water column (Lima et al. 2014). Filter feeder fishes have unselective feeding behavior and it is more vulnerable to ingest microplastics than other marine fishes (Rummel et al. 2016). Microplastics can be ingested directly or indirectly through the transfer of contaminated prey, and intentionally through mistaken of prey or unintentionally due to filter-feeding behavior (Ryan 2016).

Table 2. Comparison of ingested microplastics in fish worldwide

\begin{tabular}{|c|c|c|c|c|c|c|}
\hline Region & Fishes group & $\begin{array}{c}\text { Percent } \\
\text { of } \\
\text { ingestion } \\
(\%) \\
\end{array}$ & $\begin{array}{c}\text { Fish with } \\
\text { microplastics } \\
\text { (individual) }\end{array}$ & $\begin{array}{c}\text { Number of } \\
\text { microplastic } \\
\text { particles }\end{array}$ & $\begin{array}{c}\text { Average (range) } \\
\text { microplastic } \\
\text { particles } \\
\text { per individual }\end{array}$ & Reference \\
\hline Mediterranean Sea & Marine fishes & 58 & 771 & 1822 & $2.36(1-35)$ & Guven et al. (2017) \\
\hline Texas Gulf Coast & Marine fishes & 42.4 & 585 & 1141 & $1.93(0-32)$ & Peters et al. (2017) \\
\hline Mondego Estuary Portugal & Commercial fishes & 38 & 46 & 157 & $1.67 \pm 0.27$ & Bessa et al. (2018) \\
\hline Sydney Harbour & Estuary fishes & 43 & 40 & 249 & $(0.2-4.6)$ & Halstead et al. (2018) \\
\hline South Pacific tropical gyre & Commercial fishes & 24.3 & 226 & 550 & $2.4 \pm 0.2$ & Markic et al. (2018) \\
\hline Pantai Indah Kapuk coast & Commercial fishes & 97.13 & 169 & 2063 & $12.21 \pm 9.76(0-52)$ & This study \\
\hline
\end{tabular}


This study classified the collected fishes into 2 groups based on their different diet, herbivore, and carnivore. Oreochromis mossambicus, Scatophagus argus, Crenimugil seheli, Chanos chanos, and Mugil cephalus were classified as herbivorous fishes. While Sardinella fimbriata, Siganus canaliculatus, Abalistes stellaris, and Anodontostoma chacunda were classified as carnivore fishes. Average number of microplastic particles per species was lower in herbivorous fishes than in carnivorous fishes. These results were consistent with Manalu (2017) who found that microplastic particles were high in Eleutheronema tetradactylum, Neotrygon annotate, Nemipterus marginatus, Anodontostoma chacunda, and Selar boops as carnivorous fishes. The microplastics were ingested by carnivore or large predatory fish because of mistaken prey or trophic transfer from prey to predator (Boerger et al. 2010; Lusher et al. 2013; Markic et al. 2018). According to Markic et al. (2018), plastic ingestion by herbivorous fish was approximately 3.5 times higher than by carnivorous fish during 24-hour period. Microplastics accumulation may be greater in carnivorous fish than in herbivorous fish, so the number of identified microplastics may be greater in carnivorous fish than herbivorous fish. However, Guven et al. (2017) stated that the number of ingested microplastic was not influenced by trophic transfer. The density of microplastics in habitat may be the main factor of microplastic ingestion (Guven et al. 2017; Pazos et al. 2017; Markic et al. 2018). Microplastics were higher in pelagic fishes than in demersal fishes whereas there was not significantly different (Lusher et al. 2013; Rummel et al. 2016; Guven et al. 2017; McGoran et al. 2018).

\section{Type of ingested microplastic}

The potential of microplastics ingestion is influenced by type or shape (Boerger et al. 2010). Effects of microplastics on fish are different based on their type (Choi et al. 2018). The majority of plastic particles in this study were fibers and it was similar to the results of previous studies (Lusher et al. 2013; Philips and Bonner 2015; Rummel et al. 2016; Bellas et al. 2016; Guven et al. 2017; Peters et al. 2017; Pazos et al. 2017; Baalkhuyur et al. 2018; Bessa et al. 2018; McGoran et al. 2018; Compa et al. 2018; Horton et al. 2018), followed by fragment (Bessa et al. 2018; Compa et al 2018; Horton et al. 2018) or hard plastic (Guven et al. 2017), and film (Horton et al. 2018). Type of ingested microplastic is related to the feeding behavior of examined fish. Omnivorous fishes often ingested fibers, while fragments were mostly ingested by benthic organisms (Markic et al. 2018).

Fiber has lower size and density than fragment and film due to its polymer composition. Fibers, small films, and fragment are commonly found in surface water and water column, while large films and fragments are common in sediments. Films were the most abundant in mangrove sediment of Pantai Indah Kapuk coast, while fibers and fragments were found in similar density (Hastuti 2014). The size of ingested films in recent study was bigger than fragments. It indicated that small fragments and medium films tend to float in water column. Large fragments and films tend to sink and settle in sediment due to their size, density, and substrate accumulated on the surface. Pelagic and bathypelagic feeders mostly ingest plastic bags or films, whereas bathybenthic feeders mostly ingest the hard plastics or fragments (Anastasopoulou et al. 2013).

\section{Colors of microplastic ingested}

The most abundant of ingested microplastic in this study were transparent, blue, red, black, and green particles. Similar color was observed in other previous studies (Alomar et al. 2017; Baalkhuyur et al. 2018; Bessa et al. 2018; Bellas et al. 2016; Digka et al. 2018; Compa et al. 2018; Guven et al. 2017). The examined fishes ingested phytoplankton and zooplankton as their natural prey. The colors of white, clear, and blue are similar to the colors of plankton (Boerger et al. 2010). The color of microplastic particles in environment increases the potential of ingestion because of the similarity to natural prey. According to Ory et al. (2018b), blue microplastics were similar to color of copepods in the South Pacific Ocean.

However, Christian Ory et al. (2018) predicted the model of microplastics ingestion. First model, fish are more vulnerable to ingest microplastics because of the similarity to their prey. Second model, fish may avoid microplastics that appear different from their prey, but may accidentally ingest microplastics when they float close to the natural prey. Planktivorous fishes in this study tended to ingest microplastics because they close to natural prey as a result of unselective feeding. It indicated that the potential of microplastics ingestion depends on the occurrence of microplastics in their habitat. It meant that ingested microplastics may have similar characteristics to microplastics from their habitat. Ory et al. (2018b) found a similar finding that microplastics found in several different colors suggest that the colors of microplastics do not influence the ingestion, even though the colors composition of microplastics in environment are similar to the colors of plankton. Boerger et al. (2010) also found that microplastic ingestion by pelagic fish in North Pacific Gyre was not influenced by color.

\section{Size of ingested microplastics}

The size fraction of microplastics is the main factor due to their bioavailability to the lowest trophic level. The plastic particles are able to block the digestive tract based on their size. According to Boerger et al. (2010), ingested plastics that are not able to pass through the digestive tract can be accumulated and lead to starvation, malnutrition, until death. Accumulation of microplastics particles in digestive tract also leads to the dissolution of chemical components and the transportation the chemical components into the organs (Teuten et al. 2007).

The size of microplastics also influences the selectivity of ingestion and translocation to body tissue. The selective ability to catch the prey may be low because the size of microplastics is similar to the size of plankton as natural prey (Moore 2008). Microplastics were introduced into the food web by feeding at one trophic level then transferring to higher trophic level based on their size (Farrel and Nelson 2013). The potential of microplastics translocation 
to the fish tissue may increase with a reduction in the size of plastic particles. As the finding of Collard et al. (2018), microplastic particles can be translocated into the liver of wild freshwater fish, while no microplastics were detected in muscle tissue. Polystyrene microplastics accumulated in gut $>$ gills $>$ liver and brain of Oreochromis niloticus (Ding et al. 2018).

The size range of particles found in this study was relatively lower than the finding of some previous studies. This study found fibers ranging between $<20$ to $3000 \mu \mathrm{m}$, films in various abundance with size ranging between $<200$ to $100.000 \mu \mathrm{m}^{2}$, and fragments ranging between $<100$ to $5000 \mu \mathrm{m}^{2}$. The other previous studies found ingested microplastics ranging between 1000-2790 $\mu \mathrm{m}$ in planktivorous fish in the North Pacific Central Gyre (Boerger et al. 2010), 100-500 $\mu \mathrm{m}$ were predominantly found in fish from Northern Ionian Sea while $<100 \mu \mathrm{m}$ were mostly found in Sardines as filter feeder (Digka et al. 2018), 150-3000 $\mu \mathrm{m}$ for fiber in pelagic and demersal fishes from North Sea and Baltic Sea (Rummel et al. 2016), 380-3100 $\mu \mathrm{m}$ in demersal fish from Spanish Atlantic and Mediterranean coasts (Bellas et al. 2016). The differences of the particles size range of those studies cues the different species and the body size of examined fish. Different organisms ingest different microplastics and it is depended on the size and abundance of particles (Setala et al. 2014). However, the comparison of particles size with other studies was difficult to be determined because many other studies quantified all type of microplastics in length, not in width.

The size range of ingested microplastics in this study was similar to the size of plankton. Tintinnopsis lobiancoi has a body size of 2.8 - $23.8 \mu \mathrm{m}$ (Setala et al. 2014). Copepod has a body size of $400-1000 \mu \mathrm{m}$, while Chaetognaths has body size 4000-10000 $\mu \mathrm{m}$ (Figueiredo and Moraes Pintas Vianna 2018). The large fragments $\left(>1000 \mu \mathrm{m}^{2}\right.$ ) in this study were only found in carnivorous fishes (Anodontostoma chacunda, Abalistes stellaris, Siganus canaliculatus, and Sardinella fimbriata). This result suggested that carnivorous fishes in similar body size with herbivorous fishes tend to feed on the larger prey. The natural preys of carnivorous fishes, such as crustaceans have a larger size than phytoplankton. So, the large microplastics that close to their prey may be co-captured by carnivorous fishes. The finding of Di Mauro et al. (2017) supported these results that the size of microplastics partially or completely overlapped with zooplankton, suggesting the potential of mistaken for natural prey. Daphnia magna as carnivorous prey ingested plastic microbeads at size of 63-75 $\mu \mathrm{m}$ (Canniff and Hoang 2018) and long fibers around $300 \mu \mathrm{m}$ (Jemec et al. 2016). It is potentially transported into planktivorous fishes via transfer trophic.

\section{Ingested microplastics related to body size}

All examined samples in this study were adult fishes. Ferreira et al. (2018) found that adult fishes had the most contaminated ontogenetic phase; they ingested almost all organisms whose guts have been contaminated with microplastics. Ramos et al. (2012) also found that the higher number of microplastics were in adult, subadult, and juvenile phase respectively. This study collected a similar size of fish from each species and found various numbers of microplastics in their digestive tract. So that in the same species, there was no correlation between the numbers of ingested microplastics, either total body weight or total body length. Some other previous studies found similar results that there was no correlation between the amount of ingested microplastic and either fish length (Alomar et al. 2017; Guven et al. 2017; Pazos et al. 2017; Vendel et al. 2017; Digka et al. 2018; Horton et al. 2018), sex (Guven et al. 2017; Horton et al. 2018), total body weight (Peters et al. 2016; Guven et al. 2017; Pazos et al. 2017; Halstead et al. 2018; Pegado et al. 2018), feeding habit (Guven et al. 2017; Pazos et al. 2017), or trophic level (Guven et al. 2017; Pegado et al. 2018). Chen et al. (2017) even found that larval body length was significantly reduced by $6 \%$ due to nanoplastic ingestion by zebrafish (Danio rerio).

In contrast, some previous studies showed that the number of ingested microplastics was statistically and positively correlated to fish weight (Horton et al. 2018) and fish length (Peters et al. 2016; Pegado et al. 2018). The larger fishes had more plastics in their digestive tract than smaller fishes (Boerger et al. 2010; Compa et al. 2018).

These differences were due to the differences of species, ontogenetic phase, the number of examined fish, the size of examined fish, the abundance of microplastics in marine environment, and retention time of ingested microplastics. It was not possible to determine the differences in ingestion rates at different ontogenetic phase without knowing the retention time of ingested plastics in each phase (Boerger et al. 2010).

\section{Ingested microplastics related to digestive tract content}

The size of digestive tract was related to feeding behavior. In this study, Carnivorous fishes that had shorter digestive tract than herbivorous fishes contain higher number of microplastics. In fact, in the same species, there was no correlation between the number of ingested microplastics and neither digestive tract length nor digestive content weight. Some previous study reported the similar findings that there was no correlation between the number of ingested microplastic and fullness index (Anastasopoulou et al. 2013) and gut content weight (Halstead et al. 2018). Foley et al. (2018) also stated that ingested microplastics may give negative impact because they reduce consumption of natural prey. So, if the fish ingest more microplastics, large plastics mainly, the amount of ingested natural prey is going to decrease because the plastics may block the digestive tract.

In contrast, some other studies showed that there was a significant positive correlation between the numbers of ingested microplastic and the gut fullness index (Markic et al. 2018) and stomach weight (Peters et al. 2016). It indicated that the number of ingested microplastics increase with the amount of digestive content. The difference of species and the retention time of food in gut of each species may be important factors. According to Christian Ory et al. (2018), microplastics are less easily digested by fish than food because microplastics remained 
in Seriolella violacea (planktivorous fish) guts for a week, while food remained for, maximum, 2 days. In contrast, Grigorakis et al. (2017) showed that microplastics were not able to accumulate within the gut contents over a successive meal because the retention time of microplastics was similar to retention time of digestive content.

Future research is needed to determine the residence time of microplastics in digestive tract of each commercial fishes species. The occurrence of microplastics and chemical contaminants in body tissue is also required to explain the risks for human health.

\section{ACKNOWLEDGEMENTS}

We would like to thank Balai Besar Sumber Daya Alam Provinsi DKI Jakarta for entry permission in conservation areas. We also greatly appreciate Ecobiology and Conservation of Aquatic Resources Laboratory for materials support.

\section{REFERENCES}

Alomar C, Sureda A, Capo X, Guijarro B, Tejada S, Deudero S. 2017. Microplastic ingestion by Mullus surmuletus Linnaeus, 1758 fish and its potential for causing oxidative stress. Environ Res 159: 135-142.

Alvarez G, Barros A, Velando A. 2018. The use of Europian shag pellets as indicators of microplastic fibers in the marine environment. Mar Pollut Bull 137: 444-448.

Anastasopoulou A, Mytilineou C, Smith CJ, Papadopoulou KN. 2013. Plastic debris ingested by deep-water fish of the Ionian Sea (Eastern Mediterranean). Deep-Sea Res I 174: 11-13.

Baalkhuyur FM, Bin Dohaish EA, Elhalwagy MEA, Alikunhi NM, AlSuwailem AM, Rostad A, Coker DJ, Berumen ML, Duarte CM. 2018. Microplastic in the gastrointestinal tract of fishes along the Saudi Arabian Red Sea coast. Mar Pollut Bull 131: 407-415.

Bellas J, Martinez-Armental J, Martinez-Camara A, Besada V, MartinezGomez C. 2016. Ingestion of microplastics by demersal fish from the Spanish Atlantic and Mediterranean coasts. Mar Pollut Bull 109: $55-$ 60.

Bessa F, Barria P, Neto JM, Frias JPGL, Otero V, Sobral P, Marques JC. 2018. Occurrence of microplastics in commercial fish from a natural estuarine environment. Mar Pollut Bull 128: 575-584.

Boerger CM, Lattin GL, Moore SL, Moore CJ. 2010. Plastic ingestion by planktivorous fishes in the North Pacific Central Gyre. Mar Pollut Bull 60: 2275-2278.

Browne MA, Niven SJ, Galloway TS, Rowland SJ, Thompson RC. 2013 Microplastic moves pollutants and additives to worms, reducing functions linked to health and biodiversity. Curr Biol 23: 2388-2392.

Canniff PM, Hoang TC. 2018. Microplastic ingestion by Daphnia magna and its enhancement on algal growth. Sci Total Environ 633: 500-507.

Chen Q, Gundlach M, Yang S, Jiang J, Velki M, Yin D, Hollert H. 2017. Quantitative investigation of the mechanisms of microplastics and nanoplastics toward zebrafish larvae locomotor activity. Sci Tot Environ 584-585: 1022-1031.

Cheung PK, Fok L, Hung PL, Cheung LTO. 2018. Spatio-tempora comparison of neustonic microplastic density in Hong Kong waters under the influence of the Pearl River Estuary. Sci Tot Environ 628629: 731-739.

Choi JS, Jung Y, Hong N, Hong SH, Park J. 2018. Toxicological effects of irregularly shaped and spherical microplastics in a marine teleost, the sheepshead minnow (Cyprinodon variegatus). Mar Pollut Bull 129: 231-240.

Christian Ory N, Gallardo C, Lenz M, Thiel M. 2018. Capture, swallowing, and egestion of microplastics by a planktivorous juvenile fish. Environ Pollut 240: 566-573.
Claessens M, De Meester S, Van Landuyt L, De Clerck K, Janssen CR. 2011. Occurrence and distribution of microplastics in marine sediments along the Belgian coast. Mar Pollut Bull 62: 2199-2204.

Collard F, Gasperi J, Gilbert B, Eppe G, Azimi S, Rocher V, Tassin B. 2018. Anthropogenic particles in the stomach contents and liver of the freshwater fish Squalius cephalus. Sci Tot Environ 643: 1257-1264.

Carreras-Colom E, Constenla M, Soler-Membrives A, Cartes JE, Baeza M, Padros F, Carrasson M. 2018. Spatial occurrence and effects of microplastic ingestion on the deep-water shrimp Aristeus antennatus. Mar Pollut Bull 133: 44-52.

Compa M, Ventero A, Iglesias M, Deudero S. 2018. Ingestion of microplastics and natural fibres in Sardina pilchardus (Walbaum, 1792) and Engraulis encrasicolus (Linnaeus, 1758) along the Spanish Mediterranean coast. Mar Pollut Bull 128: 89-96.

Costa MF, Silva-Cavalcanti JS, Barbosa CC, Portugal JL, Barletta M. 2011. Plastics buried in the inter-tidal plain of a tropical estuarine ecosystem. J Coast Res Speci Issue 64: 339-343.

Cristina Fossi M, Panti C, Guerranti C, Coppola D, Giannetti M, Marsili L, Minutoli R. 2012. Are baleen whales exposed to the threat of microplastics? A case study of the Mediterranean fin whale (Balaenoptera physalus). Mar Pollut Bull 64: 2374-2379.

Digka N, Tsangaris C, Torre M, Anastasopoulou A, Zeri C. 2018. Microplastics in mussels and fish from the Northern Ionian Sea. Mar Pollut Bull 135: 30-40.

Ding J, Zhang S, Mamitiana Razanajatovo R, Zou H, Zhu W. 2018. Accumulation, tissue distribution, and biochemical effects of polystyrene microplastics in the freshwater fish red tilapia (Oreochromis niloticus). Environ Pollut 238: 1-9.

Di Mauro R, Kupchik MJ, Benfield MC. 2017. Abundant plankton-sized microplastic particles in shelf waters of the northern Gulf of Mexico. Environ Pollut 230: 798-809.

Enders K, Lenz R, Stedmon CA, Nielsen TG. 2015. Abundance, size and polymer composition of marine microplastics $10 \mu \mathrm{m}$ in the Atlantic Ocean and their modelled vertical distribution. Mar Pollut Bull 100: 70-81.

Farrell P, Nelson K. 2013. Trophic level transfer of microplastic: Mytilus edulis (L.) to Carcinus maenas (L.). Environ Pollut 177: 1-3.

Ferreira GVB, Barletta M, Lima ARA, Morley SA, Justino AKS, Costa MF. 2018. High intake rates of microplastics in a Western Atlantic predatory fish, and insights of a direct fishery effect. Environ Pollut 236: 706-717.

Figueiredo GM, Moraes Pintas Vianna T. 2018. Suspended microplastics in a highly polluted bay: Abundance, size, and availability for mesozooplankton. Mar Pollut Bull 135: 256-265.

Foley CJ, Feiner ZS, Malinich TD, Hook TO. 2018. A meta-analysis of the effects of exposure to microplastics on fish and aquatic invertebrates. Sci Tot Environ 631-632: 550-559.

Frias JPGL, Otero V, Sobral P. 2014. Evidence of microplastics in samples of zooplankton from Portuguese coastal waters. Mar Environ Res 95: 89-95.

Grigorakis S, Mason SA, Drouillard KG. 2017. Determination of the gut retention of plastic microbeads and microfibers in goldfish (Carassius auratus). Chemosphere 169: 233-238.

Goss H, Jaskiel J, Rotjan R. 2018. Thalassia testudinum as a potential vector for incorporating into benthic marine food webs. Mar Pollut Bull 135: 1085-1089.

Guven O, Gokdag K, Jovanovic B, Erkan Kideys A. 2017. Microplastic litter composition of the Turkish territorial waters of the Mediterranean Sea, and its occurrence in the gastrointestinal tract of fish. Environ Pollut 223: 286-294

Halstead JE, Smith JA, Carter EA, Lay PA, Johnston EL. 2018. Assessment tools for microplastics and natural fibers ingested by fish in an urbanised estuary. Environ Pollut 234: 552-561.

Hastuti AR. 2014. Distribusi spasial sampah laut di ekosistem mengrove Pantai Indah Kapuk Jakarta. [Undergraduate thesis]. Institut Pertanian Bogor, Bogor. [Indonesian].

Hidalgo-Ruz V, Gutow L, Thompson RC, Thiel M. 2012. Microplastics in the marine environment: A review of the methods used for identification and quantification. Environ Sci Technol 46: 3060-3075.

Horton AA, Jurgens MD, Lahive E, van Bodegom PM, Vijver MG. 2018. The influence of exposure and physiology on microplastic ingestion by the freshwater fish Rutilus rutilus (roach) in the River Thames, UK. Environ Pollut 236: 188-194.

Ivar do Sul JA, Costa MF. 2013. Plastic pollution risks in an estuarine conservation unit. J Coast Res 65: 48-53. 
Jemec A, Horvat P, Kunej U, Bele M, Krzan A. 2016. Uptake and effects of microplastic textile fibers on freshwater crustacean Daphnia magna. Environ Pollut 219: 201-209.

Lattin GL, Moore CJ, Zellers AF, Moore SL, Weisberg SB. 2004. A comparison of neustonic plastic and zooplankton at different depths near the southern California shore. Mar Pollut Bull 49: 291-294.

Lima ARA, Costa MF, Barletta M. 2014. Distribution patterns of microplastics within the plankton of a tropical estuary. Environ Res 132: $146-155$

Lusher AL, McHugh M, Thompson RC. 2013. Occurrence of microplastics in the gastrointestinal tract of pelagic and demersal fish from the English Channel. Mar Pollut Bull 67: 94-99.

Lusher AL, Hernandez-Milian G, O'Brien J, Berrow S, O'Connor I, Officer R. 2015. Microplastic and macroplastic ingestion by a deep diving, oceanic cetacean: The True's beaked whale Mesoplodon mirus. Environ Pollut 199: 185-191.

Manalu AA. 2017. Kelimpahan mikroplastik di Teluk Jakarta. [Thesis] Institut Pertanian Bogor, Bogor. [Indonesian].

Manalu AA, Haryadi S, Wardiatno Y. 2017. Microplastics abundance in coastal sediments of Jakarta Bay, Indonesia. AACL Bioflux 10 (5): 1164-1173.

Markic A, Niemand C, Bridson JH, Mazouni-Gaertner N, Gaertner J, Eriksen M, Bowen M. 2018. Double trouble in the South Pacific subtropical gyre: Increased plastic ingestion by fish in the oceanic accumulation zone. Mar Pollut Bull 136: 547-564.

McGoran AR, Cowie PR, Clark PF, McEvoy JP, Morritt D. 2018. Ingestion of plastic by fish: A comparison of Thames Estuary and Firth of Clyde populations. Mar Pollut Bull 137: 12-23.

Moore CJ. 2008. Synthetic polymers in the marine environment: A rapidly increasing, long-term threat. Environ Res 108 (2): 131-139.

Neves D, Sobral P, Lia Ferreira J, Pereira T. 2015. Ingestion of microplastics by commercial fish off the Portuguese coast. Mar Pollu Bull 101: 119-126.

National Oceanic and Atmospheric Administrationn, NOAA. 2013 Programmatic Environmental Assessment (PEA) for the NOAA Marine Debris Program (MDP). National Ocean Service, NOAA, Maryland

Nor NHM, Obbard JP. 2014. Microplastics in Singapore's coastal mangrove ecosystems. Mar Pollut Bull 79: 278-283.

Ory N, Chagnon C, Felix F, Fernandez C, Lia Ferreira J, Gallardo C, Garces Ordonez O, Henostroza A, Laaz E, Mizraji R, Mojica H, Murillo Haro V, Ossa Medina L, Preciado M, Sobral P, Urbina MA Thiel M. 2018. Low prevalence of microplastic contamination in planktivorous fish species from the southeast Pacific Ocean. Mar Pollut Bull 127: 211-216

Pazos RS, Maiztegui T, Colautti DC, Paracampo AH, Gomez N. 2017. Microplastics in gut contents of coastal freshwater fish from Rio de la Plata estuary. Mar Pollut Bull 122: 85-90.

Pegado TSS, Schmid K, Winemiller KO, Chelazzi D, Cincinelli A, Dei L, Giarrizzo T. 2018. First evidence of microplastic ingestion by fishes from the Amazon River estuary. Mar Pollut Bull 133: 814-821.

Peters CA, Bratton SP. 2016. Urbanization is a major influence on microplastic ingestion by sunfish in the Brazos River Basin, Central Texas, USA. Environ Pollut 210: 380-387.

Peters CA, Thomas PA, Rieper KB, Bratton SP. 2017. Foraging preferences influence microplastic ingestion by six marine fish species from the Texas Gulf Coast. Mar Pollut Bull 124: 82-88.

Phillips MB, Bonner TH. 2015. Occurrence and amount of microplastic ingested by fishes in watersheds of the Gulf of Mexico. Mar Pollut Bull 100: 264-269.
Pinto da Costa J, Santos PSM, Duarte AC, Rocha-Santos T. 2016. (Nano) plastics in the environment-Source, fates and effects. Sci Tot Environ 566-567: 15-26

Qu X, Su L, Li H, Liang M, Shi H. 2018. Assessing the relationship between the abundance and properties of microplastics in water and in mussels. Sci Tot Environ 621: 679-686.

Ramos JAA, Barletta M, Costa MF. 2012. Ingestion of nylon threads by Gerreidae while using a tropical estuary as foraging grounds. Aquat Biol 17: 29-34.

Rummel CD, Loder MGJ, Fricke NF, Lang T, Griebeler E, Janke M, Gerdts G. 2016. Plastic ingestion by pelagic and demersal fish from the North Sea and Baltic Sea. Mar Pollut Bull 102: 134-141.

Ryan PG. 2016. Ingestion of plastics by marine organisms. In: Takada H, Karapanagioti HK (eds). Hazardous Chemicals Associated with Plastics in the Marine Environment. Springer International Publishing, Switzerland.

Setala O, Fleming-Lehtinen V, Lehtiniemi M. 2014. Ingestion and transfer of microplastics in the planktonic food web. Environ Pollut 185: 7783

Simanjuntak CPH, Sulistiono, Rahardjo MF, Zahid A. 2011. Iktiodiversitas di perairan Teluk Bintuni, Papua Barat. Jurnal Iktiologi Indonesia 11: 107-126.

Smith SDA. 2012. Marine debris: A proximate threat to marine sustainability in Bootless Bay, Papua New Guinea. Marine Pollution Bulletin 64:1880-1883

Stevenson C. 2011. Plastic Debris in the California Marine Ecosystem: A Summary of Current Research, Solution Strategies and Data Gaps: Synthetic Report. California Ocean Science Trust, University of Southern California Sea Grant, Oakland.

Su L, Cai H, Kolandhasamy P, Wu C, Rochman CM, Shi H. 2018. Using the Asian clam as indicator of microplastic pollution in freshwater ecosystems. Environ Pollut 234: 347-356.

Teuten EL, Rowland SJ, Galloway TS, Thompson RC. 2007. Potential for plastics to transport hydrophobic contaminants. Environ Sci Technol 41: 7759-7764.

Teuten EL, Saquing JM, Knappe DRU, Barlaz MA, Jonsson S, Bjorn A, Rowland SJ, Thompson RC, Galloway TS, Yamashita R. 2009. Transport and release of chemicals from plastics to the environment and to wildlife. Philosophical Transactions of the Royal Society B 364: 2027-2045.

Thompson RC, Olsen Y, Mitchell RP, Davis A, Rowland SJ, John AWG, McGonigle D, Russell AE. 2004. Lost at sea: Where is all the plastic? Science 304: 838

[UNEP] United Nations Environment Programme. 2011. UNEP Year Book 2011: Emerging Issues in Our Global Environment. UNEP, Nairobi.

Van Cauwenberghe L, Claessens M, Vandegehuchte MB, Mees J, Janssen CR. 2013. Assessment of marine debris on the Belgian Continental Shelf. Mar Pollut Bull 73: 161-169.

Van Cauwenberghe L, Janssen CR. 2014. Microplastics in bivalves cultured for human consumption. Environ Pollut 193: 65-70.

Vendel AL. Bessa F, Alves VEN, Amorim ALA. Patricio J, Palma ART. 2017. Widespread microplastic ingestion by fish assemblages in tropical estuaries subjected to anthropogenic pressures. Mar Pollut Bull 117: 448-455.

Wright SL, Thompson RC, Galloway TS. 2013. The physical impacts of microplastics on marine organisms: A review. Environ Pollut 178: 483-492. 